Original Article

\title{
SALIVARY CORTISOL LEVELS IN MOTHERS OF CHILDREN WITH AUTISM - A BIOCHEMICAL STUDY
}

\author{
Anshad Mohamed Abdulla ${ }^{1}$, Amitha M. Hegde ${ }^{2} \&$ Manju Gopakumar \\ ${ }^{1}$ P.G. Student, ${ }^{2}$ Professor \& HOD, Reader, Department of Pedodontics \& Preventive Dentistry, \\ A.B. Shetty M emorial Institute of Dental Sciences, Nitte University, M angalore - 575 018, Karnataka, India. \\ Correspondence : \\ Amitha M. Hegde \\ Professor \& H O D, Department of Pedodontics \& Preventive Dentistry, A.B. Shetty Memorial Institute of Dental Sciences, \\ Nitte University, M angalore - 575 018, Karnataka, India. \\ Mobile : +919686090880E-mail : amipedo9@gmail.com
}

\begin{abstract}
:
Background: Cortisol is a hormonal marker of stress which gets released into the blood by adrenal glands during a stressful situation. M others of children with autism will usually be experiencing great psychological trauma and therefore will be under high levels of stress. This stress might disturb the health and normal physiology of these mothers thus there is a need for study on the stress markers like cortisol in mothers of children with autism.

Materials and Methods: Saliva of 20 mothers of children with autism and 20 mothers of healthy children were collected during early hours of the day ( $8-8.30 \mathrm{am}$ ) and during evenings( $4-4.15 \mathrm{pm}$ ) subjected for cortisol assay using ELISA test. RESULTS: Mothers of children with autism were found to have significantly lower levels of salivary cortisol throughout the day as compared to mothers of healthy children.
\end{abstract}

Conclusion : There is a need for interventionsfor mothers of children with autism

Keywords: Autism, Stress, Cortisol.

\section{Introduction:}

Cortisol is a hormonal marker of stress which gets released into the blood by adrenal glands during a stressful situation due to the activation of hypothalamic-pituitary-adrenal (HPA) axis. Cortisol follows a diurnal pattern, with high concentrations in the morning and a decline throughout the day, with the lowest levels in the evening and at night ${ }^{1,2}$. This circadian rhythm is well-established by the third month of infancy ${ }^{1,2}$. Cortisol plays an important role in various functions like glucose regulation, maintenance of immune system and also protein synthesis. . However $^{3}$ various studies have stated that prolonged periods of stress and activation of HPA axis can cause harmful effects like

\begin{tabular}{|c|}
\hline Access this article online \\
\hline Quick Response Code \\
\hline
\end{tabular}
suppression of immune responses, bone growth and also poor cognitive performances ${ }^{4,5,6}$.

Mothers of children with autism are usually under high levels of stress as compared mothers of healthy children due to poor psychological well-being. Various studies in the past has attributed this state of psychological distress to the behavioural problems encountered in autistic children ${ }^{7,8}$. However very few studies highlight the impact of this stress on the health of the individual as it can affect the normal physiology of the body. The present study was undertaken to examine whether the stress experienced by mothers of autistic children affected their salivary cortisol levels.

\section{Materials and Methods:}

The aim of the study was to examine the diurnal pattern of salivary cortisol levels in mothers of autistic children and mothers of healthy children and to compare them.

\section{Sample:}

The participants consisted of 20 mothers of children with autism (study group) and 20 mothers of healthy children (control group). The participants for the study group were selected from the mothers of autistic children attending a special school in Kerala, and the participants for the control group were selected from the mothers of healthy children 
reporting for dental treatment to the Department of Pedodontics and Preventive Dentistry, A.B. Shetty Memorial Institute of Dental Sciences, Mangalore. The participants selected were mothers of the children from the age group 8-12 years.

The mean age group of mothers of autistic children were 34.05 (( $S D \pm 5.987)$ and the mean age group of mothers of healthy children were $34.9((S D \pm 5.875)$.

Informed consent was obtained from the mothers and the concerned authority of the special school to conduct the study. Ethical clearance was obtained from the ethical committee of institute. Individuals who were medically compromised and who were on medication was excluded from the study.

\section{Procedure:}

Whole unstimulated saliva was collected from the study group and control group during early hours of the day (approx. 8 - $8.30 \mathrm{am}$ ) and during evenings( approx. 4 - 4.15 $\mathrm{pm}$ ) using the Zunt method $\mathrm{d}^{9}$.The individuals were instructed not to consume any food one hour prior to the collection of saliva. Approximately $5 \mathrm{ml}$ of saliva was collected from each participant and was refrigerated at $0^{\circ}$ Celsius until it was subjected for cortisol assay using ELISA test. Diametra cortisol assay kit was used for this purpose.

Statistical analysis: The data collected were statistically evaluated using paired t test with SPSS software version 11.0.

\section{Results:}

MOTHERSOF NORM ALCHILDREN (control):

I Levels of salivary cortisol in the morning for mothers of normal children ranged from 66 nanograms per millilitre $(\mathrm{ng} / \mathrm{ml})$ to $160 \mathrm{ng} / \mathrm{ml}$ with the mean level being 89.95 $\mathrm{ng} / \mathrm{ml}$ (SD+24.894). (table.1).

I Levels of salivary cortisol in the evening for mothers of normal children ranged from $41 \mathrm{ng} / \mathrm{ml}$ to $90 \mathrm{ng} / \mathrm{ml}$ with the mean level being $57.2 \mathrm{ng} / \mathrm{ml}(\mathrm{SD} \pm 14.384)$. (table.1).

\section{OTHERS OF AUTISTIC CHILDREN (STUDY GROUP):}

I Levels of salivary cortisol in the morning for mothers of autistic children ranged from $37 \mathrm{ng} / \mathrm{ml}$ to $105 \mathrm{ng} / \mathrm{ml}$ with the mean level being 58.2 $\mathrm{ng} / \mathrm{ml}(\mathrm{SD} \pm 17.289)$.(table.1).

I Levels of salivary cortisol in the evening for mothers of autistic children ranged from $23 \mathrm{ng} / \mathrm{ml}$ to $86 \mathrm{ng} / \mathrm{ml}$ with the mean level being $43.45 \mathrm{ng} / \mathrm{ml}(\mathrm{SD}+14.94)$. (table.1).

The mean age group of mothers of autistic children were 34.05 ( $(S D \pm 5.987)$ and the mean age group of mothers of healthy children were 34.9 ((SD \pm 5.875$)$.

\section{COMPARISON OF CORTISOL LEVELS IN MOTHERS OF AUTISTIC CHILDREN \& NORM ALCHILDREN:}

The diurnal variation of salivary cortisol levels in the mothers of autistic children were significantly lower in morning as well as evening with at value of 4.685 and 2.965 respectively $(P<0.005)$. The difference in the cortisol levels from morning to evening was lower in mothers of autistic children with $t$ value of -5.402 and $p \varangle 0.001$ (TABLE.1).

Table 1 : COM PARISON OF CORTISOL LEVELS IN M OTHERS OF AUTISTIC \& NORM AL CHILDREN

\begin{tabular}{|l|l|c|c|c|c|c|c|}
\hline & GROUP & N & Mean & Std. Deviation & T & Degree of freedom & Sig. (2-tailed) \\
\hline Morning & MOTHERS OF NORM AL CHILDREN & 20 & 89.95 & 24.894 & 4.685 & 38 & $\leq \mathbf{0 0 1}$ \\
\hline & MOTHERS OF AUTISTIC CHILDREN & 20 & 58.2 & 17.289 & & & \\
\hline Evening & M OTHERS OF NORM AL CHILDREN & 20 & 57.2 & 14.384 & 2.965 & 38 & $\underline{\mathbf{0 . 0 0 5}}$ \\
\hline & M OTHERS OF AUTISTIC CHILDREN & 20 & 43.45 & 14.94 & & & \\
\hline MOMDIFF & MOTHERS OF NORM AL CHILDREN & 20 & -32.75 & 13.1224 & -5.402 & 38 & $\overleftarrow{0.001}$ \\
\hline & MOTHERS OF AUTISTIC CHILDREN & 20 & -14.75 & 7.06269 & & & \\
\hline
\end{tabular}

\section{Discussion:}

Salivary cortisol levels were assessed in this study as they reliably reflected the circulating hormonal levels and thereby giving a fair amount of knowledge about the adrenal activity in a non-invasive manner ${ }^{6,10}$.
The salivary cortisol levels followed a normal diurnal rhythm in the mothers of healthy children; i.e. the levels were high in the morning and decreased in the evening. The mothers of children with autism showed lower salivary cortisol levels both in the morning as well as in the evening 
on comparison with mothers of healthy children. This cortisol profile of HPA hypo activity is in contrast to the profile exhibited during an acute stressful situation but is similar to the profile exhibited by people experiencing chronic stress like parents of children with cancer, individuals experiencing posttraumatic stress disorder and soldiersin battle $\mathrm{e}^{11,12,13}$.

As the present study was undertaken for a single day it cannot be conclusively said that mothers of children with autism can be added to the above mentioned groups experiencing chronic stress but it gives a hint about the possible physiologic interactions that chronic stress causes in this group of individuals. Further this hypo activity of cortisol hormone can have several detrimental effects like attentional problems, fatigue ${ }^{6}$ etc.

In future it would be valuable to assess cortisol patterns in mothers of young children with autism who have had a

\section{References:}

1. Corbett BA, Schupp CW, Levine S, Mendoza S. Comparing cortisol, stress and sensory sensitivity in children with autism. Autism Res 2009; 2(1): 39-49.

2. Price DA, Close GC, Fielding BA. Age of appearance of circadian rhythm in salivary cortisol values in infancy. Arch Dis Child 1983; 58(6):454-456.

3. Flinn $M$ W. Evolution and ontogeny of stress response to social challenges in the human child. Developmental Review 2006;26:138-174.

4. M cEwen B S. Protective and damaging effects of stress mediators. The New England Journal of M edicine 1998; 338: 171-179.

5. Segerstrom S C, Miller G E. Psychological stress and the human immune system: A meta-analytic study of 30 years of inquire. Psychological Bulletin 2004;130:601-630.

6. M M Seltzer, JSGreenberg, J Hong, LESmith, D M Almeida, RSStawski etal. Maternal cortisol levels and behavior problems in adolescents and adults with ASD. J Autism Dev Disord 2010; 40(4): 457-469.

7. Herring S, Gray K., Taffe J, Tonge B, Sweeney D, Einfeld S. Behavior and emotional problems in toddlers with pervasive developmental disorders and developmental delay: Associations with parental mental health and family functioning. Journal of Intellectual Disability shorter period of stress exposure than the mothers of children of older age group used in this study (8-12 years). Also the co-relation between the salivary cortisol levels and stress could be validated by conducting the present study on a larger sample size and consecutive days.

In conclusion, the present study indicated that mothers of autistic children experience chronic stress which can be due to various factors like concern for their children, anticipating behavioural problems of their children, social image etc.

Therefore interventions like behavioural modifications that reduce behavioural problems of children with autism, counselling the parents of children with autism, stress relieving exercises like meditation would enhance the heath \&quality of life of mothers of children with autism and thus should be one of the top priority for service provision in the families of children with autism.

Research 2006; 50: 874-882.

8. Lounds J J, Seltzer M M, Greenberg J S, Shattuck P.Transition and change in adolescents and young adults with autism: Longitudinal effects on maternal well-being. American Journal on Mental Retardation 2007; 112:401-417.

9. Sreebny LM, Banoczy J, Baum BJ, Edgar WM, Epstein JB, Fox PC Saliva:Its role in health and disease.IDJ 1992;42:291-304.

10. Kirschbaum C, Hellhammer D H. Salivary cortisol in psychoneuroendocrine research: Recent developments and applications. Psychoneuroendocrinology 1994; 19, 313-333.

11. Heim C, Ehlert U, Hellhammer $D H$. The potential role of hypocortisolism in the pathophysiology of stress-related bodily disorders. Psychoneuroendocrinology 2000;25:1-35.

12. Yehuda R, Boisoneau D, Lowy M T, Giller EL. Dose-response changes in plasma cortisol and lymphocyte glucocorticoid receptors following dexamethasone administration in combat veterans with and without posttraumatic stress disorder. Archives of General Psychiatry 1995 a 52:583-593.

13. M iller G E, Cohen S, Ritchey A K. Chronic psychological stress and the regulation of pro-inflammatory cytokines: A glucocorticoid-resistance model. Health Psychology 2002;21:531-541. 